\title{
The Brazilian geopolitical strategy for the South Atlantic
}

\author{
Bruno Gomes Guimarães
}

\section{INTRODUCTION ${ }^{1}$}

The South Atlantic Ocean is currently undergoing a moment of rising international importance. There have been many discoveries of mineral and oil resources on its basin that brought maritime territorial disputes back to the international agenda. Moreover, with the increasingly limited capacity of the Panama and Suez Canals (which do not support super-tankers), the relevance of the South Atlantic trade routes as a whole has augmented.

Brazil is a crucial actor in this scenario for it has the longest coastline in the South Atlantic. Brazil has almost $7500 \mathrm{~km}$ of Atlantic coastline and $80 \%$ of the Brazilian population lives near the coast, and $95 \%$ of the country's international trade is carried out through South Atlantic oceanic routes (WIESEBRON, 2013). Several natural resources were discovered in the Brazilian Exclusive Economic Zone (ZEE), but most importantly oil and gas were discovered in deep waters of the South Atlantic in 2006 (the "Pré-Sal"). In full operation, the oil reserves would make Brazil one of the world's top ten oil producers (WIESEBRON, 2013).

Furthermore, Brazil gradually enhances its role in the international system, and as an emerging power, it is important to analyze its rise to watch if it is going to be peaceful or not. That is why observing the Brazilian geopolitical strategy is vital to understanding the evolution of the international system as a whole. Therefore, this research focuses on Brazil's geopolitical strategy and its policies towards the South Atlantic, trying to

1 I thank the comments on earlier versions of this piece by fellow researchers Marcela Ávila, Julian Fitz, Jéssica Höring, Giovana Zucatto, João Arthur Reis, David Ramin Jalilvand and Iara Binta Machado and the assistance of Prof. Lucas Kerr and Prof. Analúcia Pereira. I also thank the pertinent comments of World Tensions' reviewers. 
Bruno Gomes Guimarães

explain what has been the Brazilian geopolitical strategy for the ocean since the year 2000 and considering its recent ascent in the international scene.

The research will mainly draw from Therezinha de Castro's theoretical approach to Oceanopolítica (Ocean-politics, in opposition to geo-politics) and Julian Corbett's conceptualization on naval strategy. ${ }^{2}$ The hypothesis is that Brazil seeks the command of the South Atlantic, but it still does not have the necessary conditions for this purpose. To achieve this goal, Brazil would strive to establish naval military bases and enhance naval cooperation in strategic regions of the South Atlantic, while trying to restrain the presence of extra-regional powers.

\section{THEORETICAL APPROACH}

Castro (2002) states there are many ways of delimitating the South Atlantic, especially concerning its northern part. For her the most practical way would be to consider the northern extremity of the South Atlantic to be the chokepoint between Natal, a city on the Brazilian northeastern salience, and Dakar, Senegal the northernmost Sub-Saharan country in West Africa. However, a historical delimitation is better suited for understanding its geopolitics. Regions of Portuguese colonization should be considered as a whole. Consequently, the South Atlantic's northern limit is considered to be between the northernmost part of the Brazilian coast (Amapá State) and Cape Verde. The limits to the South, East and West are easier to define: the Antarctic, the Cape of Good Hope and the Beagle/Magallanes/Drake Straits, respectively (CASTRO, 2002).

The ocean currents of the South Atlantic, albeit not as powerful a binding force as the ones in the North Atlantic, are natural

2 Beyond the inherent qualities present in Therezinha de Castro's approach, particularly concerning the geopolitics of Brazil and the South Atlantic, I have chosen to highlight her framework because it stands out as a contribution by both a civilian and a woman in a field largely dominated by the writings of members of the Armed forces and men, such as the widely known Gen. Golbery do Couto e Silva and Gen. Carlos de Meira Mattos. 
The Brazilian geopoltical strategy for the South Atlantic

connecting circuits between Africa and South America. Their importance for commercial maritime routes has been vital since Portuguese colonization, bringing together Brazil, Angola and the Gulf of Guinea. ${ }^{3}$ Moreover, islands in the South Atlantic are "security trampolines", which have served as support for these sea lanes (CASTRO, 2002).

Castro (2002) identifies three "insular trampolines", which have historically been vital for the command of the South Atlantic since the Age of Discovery from Portugal in the late $15^{\text {th }}$ century to the United Kingdom (UK) and the United States (US) today. The first is the triangle of the Ascension, Saint Helena and Tristan da Cunha Islands. It is vital for the route to the Indic Ocean and for power projection towards Sub-Saharan Africa. The second is composed by Fernando de Noronha, Trindade and Malvinas/Falkland Islands, which have served to control the route to the Pacific and the Magallanes/Beagle Strait as well as incursions towards South America. ${ }^{4}$ The third trampoline is closer to the Antarctic but interpenetrates the other two. It effectively challenges the preponderance of the African and South American continents over the other routes. The Shetland, South Sandwich, Gough and South Georgia Islands compose it.

Accordingly, three broad strategic regions can be identified for the dominion of the South Atlantic. First, the Brazilian northeast and West Africa (particularly Cape Verde and Senegal) due to the naval chokepoint between South America and Africa. Second, the three insular trampolines, because they are vital for South Atlantic sea lanes. Lastly, the Brazilian and African coasts, especially between Angola and the Gulf of Guinea to the east and Recife and Rio de Janeiro to the west, since they are interconnected by South Atlantic

\footnotetext{
3 The main cities interconnected by the South Atlantic currents are Luanda (Angola), São Tomé (São Tomé and Príncipe), Rio de Janeiro, Salvador and Recife (Brazil). Recife is particularly important for its location is where the sea current from Africa divides: one going to the North, towards the Caribbean and the other to the South, towards Rio de Janeiro (ALENCASTRO, 2000).

4 Fernando de Noronha is also strategically significant to project power from the American continent towards West Africa (CASTRO, 2002).
} 
Bruno Gomes Guimarães

currents. Consequently, a strategy for the command of the ocean as vented by our hypothesis has to take these factors into account.

Nevertheless, Corbett (1911) notices that naval warfare does not exist devoid of a context of disputes on land. Marine strategy, thus, has to be based on the assumption that war on the sea is part of war on land. Command of the sea is linked to the use of the sea for war goals. Corbett (1911) emphasizes it only exists in a state of war: "If we say we have command of the sea in time of peace it is a rhetorical expression meaning that we have adequate Naval positions; an adequate fleet to secure the command when war breaks out" (CORBETT, 1911, p. 318).

Moreover, Corbett does not believe that command of the sea means the complete destruction of the enemy fleet. For him, command of the sea does not come from unlimited freedom of action in the sea or from the control of determined territorial waters. As Proença Jr., Diniz and Raza (1999) point out, Corbett's idea of command of the sea is rather circumstantial, rooted on the ability of using the sea, not on complete dominion over it. Therefore, "Command of the sea does not mean that the enemy can do absolutely nothing, but that he cannot seriously interfere with the undertakings by which we seek to secure the object of war, or to force our will upon him" (CORBETT, 1911, p. 318, emphasis in the original). In other words, for Corbett, the command of the sea means the opponent cannot significantly obstruct war and commerce activities. The enemy may still have an active fleet, but it is incapable of changing the course of war and political outcomes.

Following this definition, Corbett (1911) considers that the command of the sea may be temporary or permanent as well as general or local. Temporary command is when one is able to prevent the enemy from interfering with a particular operation or campaign during the period required for that operation (CORBETT, 1911). Conversely, permanent command does not compute time, i.e. "when the possibility of the enemy's recovering his maritime position is too remote to be a practical consideration" (CORBETT, 1911 , p. 319). General command of the sea is achieved when the enemy is no longer able to dangerously obstruct lines of passage and communication and to defend his own. On the other hand, 
local command implies that one can prevent the enemy from interfering in one or more specific theatres of operation.

Combining Corbett's and Castro's works, the general command of the South Atlantic is expressed through the control of the insular trampolines, which suffices for the maintenance of trade routes. These islands are enough to guarantee South Atlantic sea lanes and to interfere with their use by other forces. Currently, the UK possesses most of the islands of the insular trampolines, which are also used by the US as military bases. Because both usually work together on military issues, they are considered to have permanent general command over the ocean (PENHA, 2011). Consequently, the Brazilian strategy for the command of the South Atlantic as devised in our hypothesis would have to consider diminishing Washington's and London's presence in the ocean and somehow acquiring facilities in these islands. In other words, Brazil seeks general and permanent command of the ocean.

\section{BRAZIL'S INTERNACIONAL INSERTION STRATEGY}

In the $21^{\text {st }}$ century, Brazil has pursued an international insertion strategy that privileges two main points. Regional integration is at its core. In the year 2000, after the several economic crises that afflicted South American countries in the late 1990s, Brazilian President Fernando Henrique Cardoso (1995-2002) made a counter-intuitive choice of deepening the regional integration process. When Mercosul $^{5}$ seemed to fail, the Brazilian policy actually perceived integration as a means to escape the economic crisis in the bloc: They would not be as dependent on foreign countries as before, i.e. they would diminish their vulnerability to foreign markets through integration (VIZENTINI, 2005). Cardoso, then, not only tried to bind together Mercosul member-states, but also sought to establish a continental integration process, which would later culminate in the Union of South American Nations (UNASUL) under President Lula.

5 Southern Common Market, a free trade area and customs union created by Brazil, Argentina, Paraguay and Uruguay in the 1990s. 
Bruno Gomes Guimarães

Despite their different political leanings, both shared the perception (even if Cardoso only noticed it in his last years in office) that South America should be at the core of the Brazilian international insertion strategy. President Lula, during his eight years in office, had more time to develop this strategy, which has also been followed by President Dilma Rousseff. ${ }^{6}$ In practical terms, under his presidency the country forged its leadership status by pushing forward South American integration and Mercosul's revamping. International negotiations were also strongly affected by the South American bloc, which together could ask for more concessions from developed countries. According to Vizentini (2005), the priority given to South American integration offered all neighboring countries a necessary partnership to resume economic growth and it effectively reversed the global trend towards the region's marginalization. Continental integration is thus their only global strategy to ensure development and governability in South America, while being a necessary instrument for negotiations with other countries (VIZENTINI, 2005; 2007).

Thereby, Brazil would gain more weight in the international scene, since, together, the South American countries could bargain and achieve more than negotiating alone. The idea behind this is that Brazil's future is tied to the future of its neighbors and it is only through this that Brazil can aspire to have a greater role in world politics. In fact, considering that a new balance of power is taking shape in the emerging multipolarity, Brazil tries to consolidate a united South America which is peaceful and stable. Silva (2013) and Celso Amorim (2013) argue that, if this is achieved, the continent itself could become a new pole in a multipolar world.

Thus, South American integration embodies three Brazilian goals (STUENKEL, 2013). The first is to establish the region as a shield against external interference and shocks, be they political or economic. For example, a greater integration of South American markets could protect Brazil (and other countries too) against

6 Michel Temer's Minister of Foreign Affairs, José Serra, seems to have abandoned regional cordiality and started to implement a foreign policy in which South America is no longer central (CASARÕES, 2016; REZENDE, 2016). 
The Brazilian geopoltical strategy for the South Atlantic

unfair competition coming from China or elsewhere. Similarly, political interference by the US in the affairs of the region could be avoided, if the countries together are willing to solve their problems on their own. The second goal is to create a stable and peaceful environment that enables the further development of the continent. For that, Brazil takes on the role of regional leader and its ensuing responsibilities. Stuenkel (2013) argues that Brazil may even be ready to act unilaterally to ensure regional stability. Yet, there remains a strong preference for collective action to solve South America's problems. Lastly, regional integration represents a launch pad for global power. If Brazil is seen as the leader of an integrated South America, the country's weight in global affairs would doubtlessly be greater, coming close to the status of global power.

The second part of the Brazilian international insertion strategy since 2000, along with regional integration, is the idea of establishing closer relations with other developing countries to thereby diversify global partnerships. In the words of the former Brazilian Minister of Foreign Affairs and former Minister of Defense Celso Amorim:

$$
\begin{aligned}
& \text { At the crossroads of all the main guidelines of } \\
& \text { Brazilian foreign policy is the effort to establish } \\
& \text { closer relations with other developing } \\
& \text { countries. South-South cooperation is a } \\
& \text { diplomatic strategy that originates from an } \\
& \text { authentic desire to exercise solidarity toward } \\
& \text { poorer countries. At the same time, it helps } \\
& \text { expand Brazil's participation in world affairs. } \\
& \text { Cooperation among equals in matters of } \\
& \text { trade, investment, science and technology } \\
& \text { and other fields reinforces our stature and } \\
& \text { strengthens our position in trade, finance } \\
& \text { and climate negotiations. Last but not } \\
& \text { least, building coalitions with developing } \\
& \text { countries is also a way of engaging in the } \\
& \text { reform of global governance in order to make } \\
& \text { international institutions fairer and more } \\
& \text { democratic (AMORIM, 2010, p. 231). }
\end{aligned}
$$

In practical terms, Brazil has sought partners outside the western hemisphere to amplify its influence in the international scene through a more active and pragmatic posture. Brazil thus 
Bruno Gomes Guimarães

uses South-South cooperation to balance its international insertion vis-à-vis developed countries and international capital flows. It does not mean that the country ignored its relations with the developed world nor that it abandoned established international regimes, but rather that South-South relations were used to balance the power wielded by developed countries in world politics, especially in institutions such as the United Nations (UN) and the World Trade Organization (WTO).

Hence, Brazil's relations with African countries are paramount to this strategy, because they tie together ethical principles and national interests (VIZENTINI, 2005). Moreover, relations with other emerging powers (BRICS, ${ }^{7}$ for instance) evidence the Brazilian objective of contributing to the establishment of a multipolar international system. Therefore, according to Vizentini (2005), Brazil seeks more room for bargaining and a more democratic alternative to the dominion of the developed world in international relations.

Regional integration and diversification of global partners seem to be in line with our hypothesis. To achieve the command of the South Atlantic, Brazil would have to engage regions other than the West, especially in Africa, and participate in institutions which shun western involvement. The next section will describe recent developments regarding Brazil's multilateral and bilateral relations in the South Atlantic.

\section{SOUTH ATLANTIC RELATIONS}

\subsection{Multilateral relations}

There are four multilateral frameworks for Brazilian relations with South Atlantic states: the Rio Pact, the Zone of Peace and Cooperation in the South Atlantic (ZPCSA), the Community of Portuguese-Speaking Countries (CPLP), and the South American Defense Council (SDC). Whereas the former has lost its importance and the latter's main concern is not the South Atlantic per se,

7 Brazil, Russia, India, China and South Africa.

302 | Tensões Mundiais, Fortaleza, v. 12, N. 22, P. 295-322, 2016 
The Brazilian geopoltical strategy for the South Atlantic

the ZPCSA and the CPLP have emerged as important forums for cooperation on issues regarding the ocean.

The Rio Pact (officially the Inter-American Treaty of Reciprocal Assistance) was crafted between 1936 and 1947 under the spectrum of World War II and the Cold War. ${ }^{8}$ It was based on continental solidarity and reciprocal assistance against external and internal aggression. However, there have never been regular armed forces nor institutionalization for the Pact. It is rather a defensive military alliance without means to assure its implementation. This means the countries cannot really assist each other in the event of an attack (CASTRO, 2002).

The treaty has been invoked only thrice since its inception: during the Cuban Missile Crisis, the terrorist attacks of $9 / 11$ and the Malvinas/Falkands War. The most meaningful event was the latter. For most of the Latin American states, the lack of US support to Argentina in the war against the UK has effectively proven that the Rio Pact was an outdated instrument deprived of any geopolitical value (CASTRO, 1997; 2002). It had shown that the region could not count on the US to protect them from external attacks. Right before the US started the war against Iraq in 2003, Mexico was the first country to officially withdraw from the treaty. ${ }^{9}$ Since then Nicaragua, Venezuela, Bolivia and Ecuador have followed suit, clearly showing regional discontent with the American foreign policy.

Although Brazil is still part of the Rio Pact, it tries to lessen the importance of the treaty. Especially after the creation of the South American Defense Council, Brazil perceives that the security of South America is primarily a responsibility of South American countries themselves without direct influence from the US (PAGLIARI, 2015).

8 The US was its main sponsor, fearing the rising influence of Nazi Germany and of the Soviet Union in Latin America. Its first and foremost characteristic is the collective self-defense against interventions from external powers in the Americas. The Rio Pact was regarded as the embodiment of the Monroe Doctrine ("America for Americans").

9 Cuba had already withdrawn from the treaty in 1960 after the revolution when diplomatic ties with the US were severed. 
Bruno Gomes Guimarães

Nevertheless, the SDC is not aimed at extra-regional concerns. It has arguably been the most important framework for Brazil on security issues since its inception in 2008, but its only scope is South America itself. South Atlantic issues are tangential to the agenda. Still, the SDC condemned the British occupation of the Malvinas/ Falklands and prohibited ships bearing the Falkland flag from docking in South American ports (GOMES GUIMARÃES, 2015a; 2015b).

The main multilateral framework employed by Brazil for South Atlantic affairs is the ZPCSA. In the 2000s, the forum was revitalized through Angolan initiative and Brazilian backing. It was launched in 1986 with strong Brazilian and Nigerian support. ${ }^{10}$ Both countries wanted to curb the influence of former colonialist powers in the South Atlantic and to distance the ocean from the geopolitical East-West divide of the Cold War. Therefore, the ZPCSA's establishment aimed at avoiding the presence of Weapons of Mass Destruction (WMDs) in the region as well as the presence of extraregional powers in the ocean (a move somewhat reminiscent of a "Monroe Doctrine for the South Atlantic"). Its reinvigoration in the 2000s focused rather on economic cooperation, the fight against illicit activities and organized crime, peacekeeping and peace operations, and scientific research (environmental and maritime issues). Yet, for the first time, the ZPCSA member-states called on the UK to end its occupation of the Malvinas/Falkand islands.

In 2013 Brazil proposed a further deepening of relations among ZPCSA's member-states, including over security issues. The Brazilian Defense Minister, Celso Amorim, offered to share knowhow on continental shelf mapping, capacity building for rescue operations in the sea, peace operations, and maritime surveillance through long range identification and tracking (BRASIL, 2013). Besides that, Brazil also suggested the creation of ZPCSA seminars about South Atlantic defense.

10 The initiative was supported by three South American countries and 21 African ones. The UN General Assembly recognized it almost unanimously in 1986. The US voted against it, and Germany, France, Portugal, Italy, and a few other former colonial powers abstained in the voting procedures. After the end of the Cold War, many analysts wrongly thought that ZPCSA had lost its raison d'être. 
Likewise, Brazil advocated within CPLP for the establishment of a comprehensive initiative for continental shelf mapping around the same time. There were two main tangible goals: the creation of a CPLP Ocean Atlas and the extension of the member-states' continental shelves (particularly in Africa). On security issues, Brazil hosted the Operação Felino. It was a series of military drills on the Brazilian coast within the framework of CPLP to train memberstates' Armed Forces for peace operations. In other words, Brazil wanted to create a "maritime mentality" within CPLP. Although there are members in all continents, the initiatives were directed at the South Atlantic (ABDENUR; SOUZA NETO, 2014).

Brazilian behavior in multilateral institutions concerning the South Atlantic seems to corroborate our hypothesis. On the one hand, Brazil tries to distance itself from frameworks which include the US. Eschewing the main extra-regional power of the ocean implies Brasília is pursuing greater autonomy in the region. Even if Brazilian policies do not unequivocally point to a command of the sea pursuit, they do demonstrate Brazil's willingness to at least curb extra-regional influence in the South Atlantic. On the other hand, Brasília tries to increase the state capacity of African counterparts, raising awareness on South Atlantic issues either through ZPCSA or CPLP. On both sides of the ocean, Brazil aims at strengthening South Atlantic identity, stressing common needs and worries-especially concerning maritime resources (ABDENUR; SOUZA NETO, 2014).

\subsection{South America}

\subsubsection{Argentina}

In South America, Argentina has the most security issues related to the South Atlantic. It has territorial claims over several South Atlantic islands, which are currently under British dominion, namely the Malvinas/Falklands, South Georgia and South Sandwich islands. All of which are part of the insular trampolines identified by Castro. 
Bruno Gomes GuimarÃes

Ever since the Malvinas/Falklands War in the 1980s, the Argentinean navy has been severely debilitated (PETERSEN, 2012). The country still has ambitions to revamp its fleet and upgrade it, but it has met no success due to budgetary limitations. Currently, the Argentinean Navy has 19,000 soldiers plus 7,200 civilian personnel and 2,500 marines. It possesses three tactical submarines, five destroyers, six frigates, 17 patrol vessels, 18 amphibious warships, and 26 logistical support ships (IISS, 2016).

Brazilian relations with Argentina underwent a remarkable transformation in the late 20th century, from continental rivalry to close cooperation: They are considered to be the driving motor of South American integration. Under the scope of UNASUL and the SDC, Brazil has supported the Argentinean claim over the Malvinas/Falklands.

Concerning the South Atlantic, Brazil and Argentina have staged many military exercises with their navies. Bilaterally there have been five since the year 2000 under the name "Operation Araex". With the participation of Uruguay there have been others such as Transamerica, Temperex and Atlasur. The latter also includes South Africa. All these exercises aim at confidence building between the nations. Their scenarios include the protection of sea trade routes and halting invasions (VAZ, 2011). There have also occurred the exercises called Operação Fraterno (loosely translated as Brotherly Operation), which simulates amphibious operations involving the armies as well as the navies of both countries. On some occasions, South Africa has been invited to these.

\subsubsection{Uruguay}

Brazil's relations with Uruguay have been of cooperation since the beginning of the 20th century, when the borders were agreed upon with Brazil unilaterally ceding coastal territory to Uruguay. ${ }^{11}$ Because it is a small country, the Uruguayan navy reflects this characteristic. It comprises 5,400 soldiers, including the coast guard. There is also a naval infantry of 450 soldiers. Uruguay possesses 33 warships: two frigates, 15 patrol vessels,

11 For a broader discussion, see Gomes Guimarães; Sebben; Duarte (2011). 
three minesweepers, three amphibious ships, and 10 for support and logistics (IISS, 2016).

Brazil also has staged several military naval exercises with Uruguay. In these, the navies simulate scenarios in which they have to keep marine trade routes free from external interference in the South Atlantic. They also engage in scenarios of combat against illegal activities, such as drug smuggling, in their territorial waters. These bilateral military exercises are called Uruex. As mentioned earlier, Uruguay has also participated in multilateral military exercises, namely Transamerica, Temperex and Atlasur.

\subsection{Sub-Saharan Africa}

\subsubsection{Nigeria}

Nigeria has been Brazil's main partner in Africa since its independence. Currently, bonds that tie them together range from trade to political and cultural ones. Their relations have been elevated to the status of a strategic partnership in 2013. Brazilian support to Nigeria's political role in its region, through the Economic Community of West African States (ECOWAS), and in the African continent as a whole, illustrates the fact.

Nigeria has the strongest navy in West Africa with 8,000 soldiers, including the coast guard. The country possesses one frigate, one corvette, 114 patrol vessels, five amphibious warships, 10 logistic and support ships and two ships for mine countermeasures (IISS, 2016). However, according to The Military Balance 2013, much of this equipment is unfit for long deployments due to deterioration (IISS, 2013). The main challenges faced by the Nigerian Navy are Niger Delta militants and piracy. Therefore, most of the procurement is focused on coastal and offshore patrol vessels.

2010 was of special significance to Brazil-Nigeria relations. It was the year when the first ECOWAS-Brazil Summit was held, in which Brazil supported Nigerian leadership once again, and a military agreement between the two countries was negotiated. In this accord, Brazil pledged to train Nigerian navy officers and provide military vessels. These programs have been ongoing since then. 
Bruno Gomes Guimarães

\subsubsection{South Africa}

South Africa's location is very strategic due to the connection between the Indic and the South Atlantic Oceans. Today approximately $60 \%$ of the oil coming from the Middle East to Europe and North America is transported by South Africa (FIORI; PADULA; VATER, 2012).

Although its Navy has historically been under British tutelage (PENHA, 2011), independent maritime security is a growing concern for South Africa due to piracy in the Indic. Having 7,650 soldiers on duty, the South African Navy is comprised of three tactical submarines, four frigates, six patrol vessels, six amphibious warships, eight ships for logistics, and two mine hunters (IISS, 2016). Were it concentrated in the South Atlantic, it would be the strongest African navy in the ocean. Yet, the country has to divide forces between both oceans. This makes the weight of the South African Navy lesser than what would be desirable (KORNEGAY, 2013; IISS, 2013).

South Africa has become one of Brazil's most important political partners, reaching the degree of strategic partnership in 2010.12 Through Brazilian initiative, South Africa was included in the BRIC forum (Brazil, Russia, India and China), now called BRICS. Moreover, another forum was developed between the two countries plus India in the 2000s, the India-Brazil-South Africa Forum (IBSA). Within these institutions Brazil has shown support for the South African role in the security arena in Southern Africa (VAZ, 2011).

A military cooperation agreement was signed between Brazil and South Africa in 2003. The navies of both countries work in close cooperation to ensure the protection of the maritime borders as well as the access to South Atlantic routes (KORNEGAY, 2013). There have been joint military exercises, namely Atlasur (with Argentina and Uruguay), IBSAMAR (with India) and Fraterno (with Argentina, too). The countries have also worked together

12 Brazil had very limited diplomatic relations with South Africa during the Apartheid. On the one hand, there was a desire to cooperate on security issues, but, on the other, Brazil tried to deepen its ties with other Sub-Saharan African countries (and, for this, relations with Pretoria were an obstacle). Once the Apartheid ended, however, bilateral relations took off (PEREIRA, 2010). 
The Brazilian geopoltical strategy for the South Atlantic

to develop the 5th generation A-Darter air-to-air missiles, which will be adapted to fit the Brazilian Gripen NG fighter jets. ${ }^{13}$ Both countries are currently further negotiating the development of cargo aircraft, surface-to-air missile, and unmanned aerial vehicles (VAZ, 2011; KORNEGAY, 2013).

\subsubsection{Angola}

Angola is one of Brazil's key partners in Africa. Not only because of their shared history, but bilateral relations have been intense since the year 2000, becoming a strategic partnership in 2010.14 Oil was one of the main reasons their ties resumed in the 1970s (Brazil sought alternative sources in the context of the oil crises). Currently, Petrobras, a Brazilian partially state-owned company, is present in Angola, where it drills deepwater oil. A myriad of other Brazilian companies is also present in Angolan markets, not to mention cultural and academic exchanges.

Angola and Brazil are very close to each other also on South Atlantic issues. They increased exchanges between their navies since 2000. The Angolan Navy has approximately 1,000 combatants and 22 patrol vessels (IISS, 2016). Despite its size, it is regionally significant (IISS, 2013). ${ }^{15}$ Brazil has also started to map the Angolan continental shelf. This program, named LEPLACA (Survey Program of the Angolan Continental Shelf), is a bilateral initiative under the aegis of ZPCSA. Within CPLP, Brazil has also been preparing the

13 In December 2013, Brazil announced the acquisition of the 4.5th generation Swedish fighter jets known as Gripen New Generation (NG). Sweden and Brazil will jointly develop the warplane, including adaptations for aircraft carriers (see OLIVEIRA et al., 2013).

14 Under Portuguese colonization, the level of commerce between the two was greater than theirs with Portugal (PENHA, 2011). In fact, when Brazil became independent, there was a strong political movement in Angola in favor of joining the Brazilian Empire instead of remaining under Portuguese colonial rule (PENHA, 2011). However, after the severance of ties due to the end of the slave trade and the British trade dominance, relations between both countries became almost non-existent. Brazil and Angola's rapprochement started in the 1970s after the latter's decolonization. Despite Brazilian right-wing dictatorship at the time and Angolan communist government, Brazil became the first country to recognize Angolan independence. Bilateral relations took off and they have remained a Brazilian priority ever since.

15 This is especially true in the context of the Gulf of Guinea. 
Bruno Gomes Guimarães

Angolan section of the organization's Ocean Atlas. Both countries also conduct joint research in the fields of shipbuilding (cargo ships), defense, and public security (FIORI; PADULA; VATER, 2012). The fall in oil prices has halted negotiations for the acquisition of Brazilian patrol-boats (IISS, 2016).

\subsubsection{Namibia}

Since Namibian independence, Brazil has cooperated with the country, especially concerning the protection of the ocean. In fact, the Brazilian Navy is the main responsible for the creation of the Namibian one. Currently it has approximately 200 soldiers for eight patrol vessels and five ships for logistics and support (IISS, 2016). Quite small, the Namibian navy is part of the Ministry of Fisheries.

Programs have been bilaterally established by Brazil with Namibia to train navy officers and sailors since the beginning of the 1990s. These were further deepened in the 2000s through the Naval Cooperation Agreement (NCA). Under it, Brazil has helped to create and train the Namibian Marine Corps, besides assisting the establishment of the Maritime Patrol Service of Namibia. To date hundreds of Namibians graduated in the Brazilian Navy War School.

Under the NCA, Brazil has also mapped the continental shelf of the country. The mapping activities ended in 2007. Brazil has also donated several warships and patrol boats to the country, most noticeably the Corvette Purus in 2004, which was decommissioned in 2012. Furthermore, Brazil has a permanent Naval Mission in Walvis Bay, one of the best natural ports in southwestern Africa. ${ }^{16}$

\subsubsection{Others}

Brazil has also increased its influence in other South Atlantic African countries since the 2000s. The energy company Petrobras has had a significant presence in offshore drilling in Gabon and

16 This permanent naval mission is not the same as a military base. There are no warships and only a few military attachés are deployed to this mission in order to regularly train Namibian marine soldiers. 
The Brazilian geopoltical strategy for the South Atlantic

Congo Brazzaville. With Guinea-Bissau, Brazil has a military agreement which helped constitute the country's first Security Forces through the Brazilian Mission of Techno-Military Cooperation (FIORI; PADULA; VATER, 2012). Warships, patrol boats, and naval uniforms were donated to the country. The same gesture was extended to São Tomé and Príncipe. ${ }^{17}$ Both Guinea-Bissau and São Tomé and Príncipe have been part of the initiative of mapping the ocean floor through the CPLP. Brazil opened an embassy in the latter in 2003 for strategic purposes: The archipelago is central for the Gulf of Guinea (AMORIM, 2013). Finally, Brazil has also sold a corvette to Equatorial Guinea in a deal which included the training of officers and sailors. Naval instructors have been sent to Benin by the Brazilian Navy. Brazil has also signed a military agreement with Senegal. More recently, in 2013, Brazil inaugurated a permanent naval mission in Cape Verde to assist in the training of coast guards.

\subsection{The 3United States}

Brazil has been cautious about the American presence in the South Atlantic. This has been so especially since the US supported a coup attempt in Venezuela in 2002 and quickly recognized the Paraguayan government after a successful coup in 2012. These resulted in smaller US political involvement in the region, but they also meant a higher military presence (BANDEIRA, 2008). ${ }^{18}$

The US Navy has traditionally divided its forces $50 / 50$ between the Atlantic and the Pacific. However, it has begun to shift this balance towards the Pacific to achieve a 40/60 division. Currently,

17 The fact that the donation of warships to these African countries has actually increased the demand in the military industry in Brazil is also noteworthy. 18 Moreover, the disclosure of classified US documents about the Brazilian military coup in 1964 has shown that the country had enormous influence in the events that took place and even had military plans to enforce the coup in case it was needed (BANDEIRA, 2008). These plans included a large naval operation in the South Atlantic (called "Big Brother") (REIS, 2011; BANDEIRA, 2008). On top of this, in the eyes of Brazil and other Latin American countries, the US did not fulfill its obligation under the Rio Pact during the Malvinas/Falklands War (CASTRO, 1997; 2002). 
Bruno Gomes Guimarães

the navy has 326,800 soldiers (IISS, 2016). The US possesses 71 submarines, 14 of which are armed with nuclear warheads. The country also has 10 aircraft carriers, 22 cruisers, 62 destroyers, four frigates, 57 patrol vessels, 11 anti-mines warships, two command ships, and 275 amphibious, besides 71 boats for logistiCS and support (IISS, 2016). The US also has an inactive fleet of one aircraft carrier, one support boat, and 12 amphibious, which can be reactivated in 60-90 days notice (IISS, 2016). The Navy Special Warfare Command has 9,850 soldiers, according to the IISS (2016), and the Marine Special Operations Command has 3,000. Besides that, the country also possesses a Military Sealift Command, which has roughly 150 ships for logistics and support. The US Coast Guard is composed of 40,000 military personnel and 8,300 civilians (IISS, 2016). It possesses 163 patrol vessels and 394 logistics and support ships (IISS, 2016).

The US is militarily present in the South Atlantic Ocean on the British Ascension Island-part of one of the insular trampolines identified by Castro (2002)-where it has one detection and tracking radar. The US is also present through the IV Fleet, which was reactivated in 2008 shortly after the discovery of huge oil fields in the Brazilian offshore. The reasons presented by the US for the reactivation were the combat against illicit trafficking and enhancing regional security (BANDEIRA, 2008) ${ }^{19}$. The US also has two military commands for the region, the USSOUTHCOM since 1963 (for South America) and the AFRICOM since 2007 (for Sub-Saharan Africa). There are 250 American soldiers deployed in Niger and 300 in Cameroon (IISS, 2016). The US also provides minor troop contributions to peace operations in Mali and Liberia. ${ }^{20}$

Regardless of the mistrust, Brazil often engages the US Navy in joint naval military exercises with other South American countries, but not regularly. ${ }^{21}$ US warships have often come to Brazilian

19 It must be noted, however, that the IV Fleet does not have any permanently assigned warships. Currently it maintains only a command structure and deployments occur only on a case by case basis.

2010 soldiers in Mali and four military observers in Liberia (IISS, 2016).

21 However, there are joint aerial military exercises twice a year. One of them, Cruzex, is considered to be the largest military exercise of Latin America. 
The Brazilian geopoltical strategy for the South Atlantic

ports to replenish supplies in the 2000s, even though there is no specific bilateral agreement for that (ALBUQUERQUE, 2010). More recently, since 2012, Brazil has participated yearly in the Obangame Express naval drills led by the US in the Gulf of Guinea. These include anti-piracy operations and combat to other illicit activities in the eastern South Atlantic. Brazilian participation set off with military observers only, but, since 2014, patrol warships have been sent to the exercises as well (COMANDO..., 2016; SOARES, 2015; ABDENUR; SOUZA NETO, 2014). Many European and African countries have taken part too.

\subsection{The United Kingdom}

Brazil is very wary of the UK in the South Atlantic - after all the country controls most of the islands of the insular trampolines identified by Castro (2002). The history of the relations between the two in the $19^{\text {th }}$ century show that Brazil has good reason to be cautious. ${ }^{22}$ Brazil backed Argentina in the Malvinas/Falklands War and it has also officially supported Argentina's claims over the South Atlantic islands under British possession. However, this has not had any effect on the relations between Brasília and London, including after the prohibition of Falkland ships from docking in South American ports issued by the SDC (FIORI; PADULA; VATER, 2012).

The British Royal Navy has 32,500 soldiers on duty. It possesses 10 submarines, four of which are armed with nuclear warheads, six destroyers, 13 frigates, 22 patrol vessels, 16 ships of mine countermeasures, three amphibious ships, and 10 ships for logistics and support (IISS, 2016). The Royal Navy does not have aircraft-carriers currently, but two new ones should be delivered soon and become fully operational as early as 2018 .

22 The UK threatened bombing Brazilian ports, raised a blockade in Rio de Janeiro and sank many ships in what was known as the Christie Incident, which culminated in the severance of diplomatic ties between the countries for a decade. Brazil in fact almost declared war against the British Empire back then. Moreover, due to the naval campaign waged by the Royal Navy against slave trade, commercial ties between Brazil and Africa were immensely affected. In fact, the blow was so strong that Brazil completely distanced itself from Africa for almost a century after that (PENHA, 2011). 
Bruno Gomes Guimarães

The UK has forces deployed throughout the South Atlantic. The most significant military presence is in the Malvinas/Falkland Islands, where approximately 1,100 troops are permanently on duty (IISS, 2016). There have been deployments to the Ascension Island, Mali and Sierra Leone of about 30 soldiers each (IISS, 2016). A Royal Navy destroyer has also been permanently patrolling the South Atlantic (IISS, 2013).

Relations have been cordial between the UK and Brazil in the $21^{\text {st }}$ century. As such, Brazil has commissioned the building of British destroyers for its Navy. These orders, however, have been made without much planning: Brazil bought them in "sellout" situations, when other countries cancelled their contracts with the UK (OLIVEIRA; CEPIK; BRITES, 2013). Quite interestingly, the British warships bought by Brazil have sailed to many South Atlantic African countries before coming to Brazil. Yet, there have been no military exercises between Brazilian and British navies since 2000 .

\subsection{France}

Similar to the UK, France has also attacked Brazilian coastal cities in the past. This engendered a very cautious behavior from Brazil, who has been very suspicious of French intentions in the South Atlantic. ${ }^{23}$ It is particularly true concerning recent French interventionism in Africa (OLIVEIRA et al., 2013).

France is militarily present in several South Atlantic African countries. As of 2016, its main deployments are in Mali, Côte D'Ivoire, Gabon, Niger, Burkina Faso and Senegal, with roughly 4,000 soldiers spread among these countries (IISS, 2016). Besides that, France maintains an amphibious assault ship on notice in the

23 The most recent incident which almost led to open war between the two countries was the so-called "Lobster War" in the 1960s. At that time, France repeatedly violated Brazilian jurisdictional waters to capture lobsters despite several warnings coming from Brasília. France and Brazil have even deployed warships to the northernmost region of the South Atlantic, but both countries agreed to diffuse tension and accepted international mediation to solve the dispute, which in the end favored Brazil (RAFFAELLI, 2003; LESSA, 1999; CARVALHO, 1999). 
The Brazilian geopoltical strategy for the South Atlantic

Gulf of Guinea (IISS, 2016). The French Navy has 38,250 soldiers, including 2,200 of the Strategic Nuclear Forces (IISS, 2016). France possesses four submarines armed with nuclear missiles, six tactical submarines, one aircraft carrier, 11 destroyers, 11 frigates, 20 patrol vessels, 18 ships for mine countermeasures, 45 amphibious ships, and 145 ships for logistics and support (IISS, 2016). Moreover, in the French Guyana-on the limits with the South Atlantic-France has around 2,100 troops and, in the Caribbean, it has 1,000 soldiers (IISS, 2016).

Yet, despite all wariness, Brazil signed a strategic military agreement with France to modernize its navy in 2008. France would jointly build with Brazil five submarines, one powered by a nuclear reactor (of Brazilian technology) and four conventional ones. France assists in the design and construction of the non-nuclear parts, mainly the hull (IISS, 2013). All submarines are to be manufactured in Brazil, meaning that it is a deal which includes technology transfer. The first one is to be delivered in 2023. Furthermore, France has also assisted Brazil with the mapping of its ocean floor. Both countries have also worked together in rescue operations in the South Atlantic between Brazil and Senegal/Cape Verde.

\section{THE SOUTH ATLANTIC IN BRAZILIAN STRATEGY}

\subsection{Domestic policies}

In 2004, the Brazilian Navy launched a concept called "Blue Amazon", which is a plea at the UN for the extension of the country's continental shelf. Map 2 depicts the area that would be added to the Brazilian territory. If the plea is fully accepted by the Commission on the Limits of the Continental Shelf (CLCS), Brazil's territory would increase 50\%. In 2007, the CLCS validated $81 \%$ of the plea. For the remaining 19\% Brazil prepared other proposals, which are currently being analyzed by the Commission (PEREIRA DA SILVA, 2013).

Since the 2000s, Brazil has adopted several policies to fully survey and protect the Blue Amazon and to guarantee its presence in the South Atlantic. Regarding maritime resources, two 
Bruno Gomes Guimarães

programs, PROAREA and Biomar, have been developed. They deal with prospection and exploration of mineral and living resources in the South Atlantic, respectively. Related to these programs, the Survey Program of the Brazilian Continental Shelf initiative was implemented. PROAREA's studies also led to a UN authorization for Brazil to explore minerals of the Rio Grande Elevation in the high seas of the ocean in 2014. ${ }^{24}$

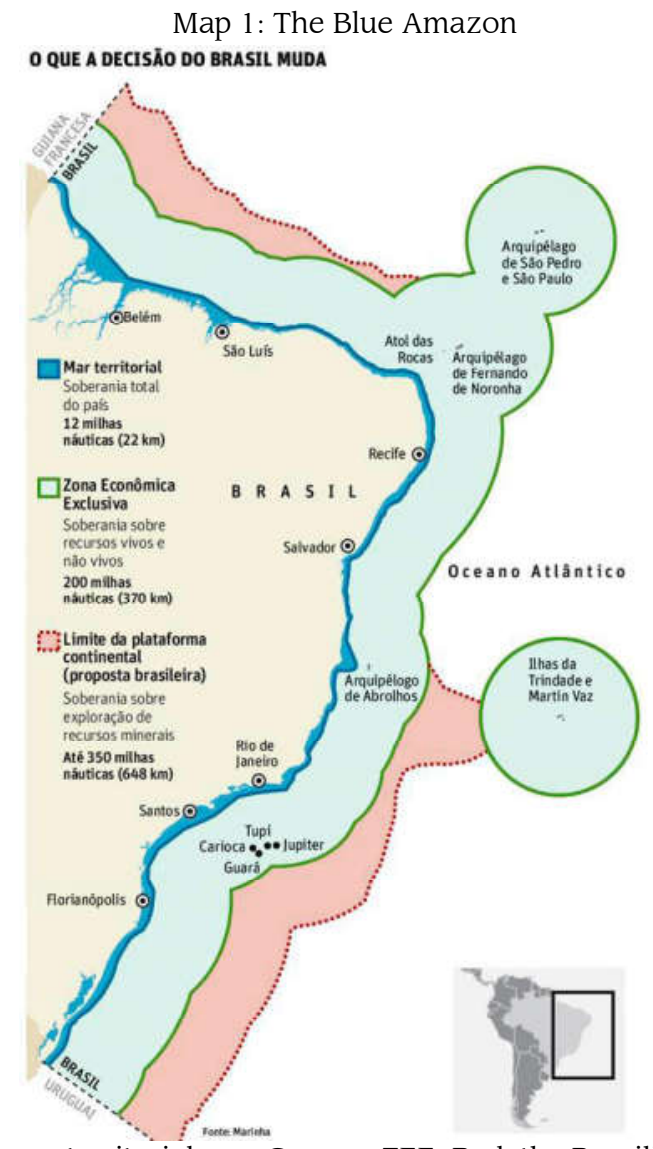

Key: Blue = territorial sea. Green = ZEE. Red: the Brazilian claim Source: Folha de S. Paulo (s.d.).

24 For more information on the Rio Grande Elevation, see Aquino et al. (2016). 
On issues of scientific research in the South Atlantic, Brazil has taken on two programs: Protrindade and Proantar. The former aims at the development of the Trindade archipelago, part of one of the insular trampolines. The latter includes initiatives which involve research of the Antarctic, survey, and exploration of neighboring cold waters of the South Atlantic. Similar to these, the Proarquipélago program is a policy for research in all Brazilian South Atlantic islands. It is implemented by the Brazilian Navy, which strives to guarantee that all islands are permanently inhabited. This way Brazil guarantees a larger ZEE in the South Atlantic.

Brazil has also started to develop the Blue Amazon Management System (SisGAAz). This system will be used for both civilian and military purposes, since it includes an ambitious surveillance system. All technologies used in SisGAAz are being designed by Brazilian companies. Although it is supposed to enter into full operation by 2027, it has been indefinitely suspended by the Navy due to budgetary constraints (STOCHERO, 2015). There is also some speculation that foreign companies might join the project (SANTAYANA, 2015).

\subsection{Current naval capabilities and procurement programs}

Brazil's Defense White Paper (2012) and the National Defense Policy (2005) state that the South Atlantic is strategic for the security of the country. Denying the command of the ocean to foreign powers is one of its main goals, which has driven the Navy's development at least since 2005.

Brazil has 69,000 soldiers on duty in its navy. The country possesses five tactical submarines, one aircraft carrier, three destroyers, 10 frigates, 48 patrol vessels, five ships for anti-mine warfare, 38 amphibious ships, and more than a hundred ships for logistics and support (IISS, 2016). Despite being the largest and strongest navy among South Atlantic countries, it is still meager in comparison with the extra-regional powers France, UK, and the US. Hence, Brazil does not feel threatened by its neighbors, but it is very apprehensive towards interference from "powers outside the 
Bruno Gomes Guimarães

region" (IISS, 2013; ALBRECHT, 2011). Brazil fears a foreign invasion of the Amazon forest as well as of the Blue Amazon. Former Brazilian Minister of Foreign Affairs and of Defense, Celso Amorim, provided examples of possible threats to Brazil which include only scenarios involving the South Atlantic. Amorim (2013) distinctively mentions the capacity of exploring deepwater oil reserves and maritime routes as Brazil's main vulnerabilities in the ocean.

Despite being the fourth largest navy of the countries considered in this paper, as can be seen on Table 1, most of the Brazilian Navy's warships and equipments need replacement and modernization (BRITES; MARTINS; SILVA, 2013). This has been Brazil's permanent goal since 2000. The Navy has carried out investments in the development of a nuclear submarine through the Submarine Development Program (PROSUB) and the Plan of Articulation and Equipment of the Brazilian Navy (PAEMB). While the nuclear technology is going to be $100 \%$ Brazilian, France is supposed to transfer technologies for the complete development of the submarine. According to the Brazilian National Defense Strategy, the country is supposed to build 15 conventional submarines plus six nuclear ones (BRASIL, 2005). There is no official deadline, even though the first ones should become operational in 2023.

The Brazilian Navy also intends to renew its surface fleet. One of the main programs for that is the PROSUPER, which plans the domestic construction of five frigates, five patrol vessels and one logistics support vessel. Several European and East Asian countries have already demonstrated their intentions of developing partnerships with Brazil for that purpose (OLIVEIRA; CEPIK; BRITES, 2013). Even so, budgetary constraints have affected most of the procurement programs aimed at modernization and acquisition of capabilities, including PROSUPER, which was suspended in 2011. PROSUB is the only program which does not suffer significantly from such problems. The construction of conventional and nuclear-powered submarines has been maintained despite economic shortcomings, while the construction and acquisition of other kinds of warships has been interrupted (ALBRECHT, 2011; 
IISS, 2013) ${ }^{25}$ However, recent fiscal austerity measures may cause a 4-year delay to PROSUB (STOCHERO, 2015).

Table 1: South Atlantic navies

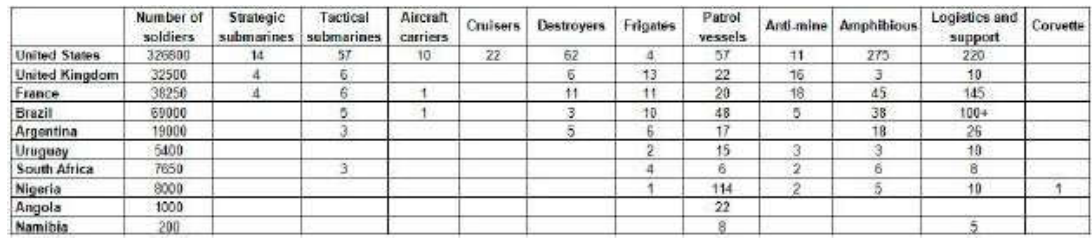

Source: made by the author with data from IISS (2016).

The Brazilian National Defense Strategy notes submarines, especially nuclear-powered ones, are essential for "sea-denial" capabilities (BRASIL, 2005; 2012). As such, Brazil wants to have a proactive posture for Blue Amazon defense. To sponsor research and business initiatives in areas related to PROSUB, Brazil created the state-owned defense company Amazul (Blue Amazon Defense Technologies) in 2012. It was activated in August 2013 and it has been providing assistance to build submarines and other warships for the Brazilian Navy. Amazul has been seen as a means to push forward PROSUPER, but its first results may come only in 2026.

Together, PROSUB, PROSUPER, and SisGAAz could grant Brazil force-projection capabilities consistent with global-power status, but delays in their procurement make everything uncertain (IISS, 2013). In the end, the modernization of the Navy:

\begin{abstract}
[...] hinges on the health of the overall economy, and on how much Brazil sees state-of-the-art military hardware necessary to sustain its international political ambitions. The absence of a conventional strategic threat in the region and, more recently, slow economic growth contribute to a reluctance to make defence spending a priority (IISS, 2013, p. 429).
\end{abstract}

Indeed, the economic crisis that hit Brazil in 2014 severely impacted the Navy's strategic projects. SisGAAz has been suspended and

25 See the work of Martins Filho $(2011 ; 2014)$ for more information about PROSUB's development through the years. 
Bruno Gomes Guimarães

PROSUB may suffer a delay of up to four years. PROSUPER remains inactive. Austerity measures taken by President Dilma Rousseff in 2015 and by Michel Temer's government in 2016 have endangered their fulfillment. Yet, they still remain priority projects within the Navy. It remains to be seen whether the current political crisis will negatively affect them in the long run.

5.3 Analysis of Brazil's geopolitical strategy towards the South Atlantic

Considering the South Atlantic relations conducted by Brazil, the country's geopolitical strategy in the 2000s appears to be rather defensive (e.g. BOHOU, 2007). On the multilateral level, Brazil fosters the ZPCSA, a South Atlantic regional grouping which does not include extra-regional powers. It has also tried to empower and foster the development of South Atlantic countries bilaterally. For sure this is not an uninterested approach since much of this bilateral cooperation also stimulates Brazil's own economic development. However, Brazilian initiatives do aim at stability in the South Atlantic. Considering that almost all of Brazil's international trade is carried out through sea routes, a war (or instability) in the ocean is undesirable.

Historically, Brazil has suffered from threats or even aggression from the extra-regional powers considered in the research: the US, France, and the UK. This has understandably created a certain suspicion in Brazil. Still, this caution has not impeded friendly engagement with them. Brazil has joined military exercises with the US and has bought warships from the UK. Partnership with France is rather deeper, since it includes assistance to submarine construction with high levels of technology transfer. This is a clear sign that Brazil's stance is not against these countries in spite of their turbulent history.

Nonetheless, it is exactly because of past experiences that Brazil has sought to increase its Navy's military capabilities, which are markedly weaker than the ones from France, the UK and the US. PROSUB, PROSUPER and SisGAAz are clear examples of an aspiration to modernize the Brazilian Navy. However, the Brazilian 
civilian and military policies towards the South Atlantic do not indicate that the country is trying to have a general command over the ocean. Mapping, research, and development programs, together with the acquisition of submarines and implementation of monitoring systems, indicate that Brazil has been struggling to guarantee a permanent local command over its jurisdictional waters only. This means that Brazil wants to make sure that no country can interfere with its civilian or military activities in the sea.

Furthermore, Brazil has tried to enhance the capabilities of African countries, but it has not sought the establishment of naval bases in the African coast. Brazil does have permanent naval missions in Namibia and Cape Verde, but they are far from being military bases of the Brazilian Navy, considering there are very few military attachés and no warships at all. These initiatives point rather to the conclusion that Brazil tries to empower those African states to make them able to deal with internal instabilities without the help of extra-regional powers, whose interventionist presence in Africa raises Brazilian discontentment. Tellingly, in 2010, Portugal put on the table the idea of extending NATO's scope to the South Atlantic and the Brazilian Minister of Defense criticized it and affirmed it would be unwelcome and detrimental to the region. ${ }^{26}$

This strategy, however, does not mean that Brazil challenges the status quo on the South Atlantic. The UK possesses most of the islands of the insular trampolines and the US has the most powerful fleet. Brazil does not seem to challenge their general command of the South Atlantic. Certainly, Brazil wants to deny them command over its jurisdictional waters, but their standing on international trading routes remains unchallenged. The only exception being the Malvinas/Falklands, in which case Brazil supports the Argentinean claim over the islands, but even then only timidly.

26 This closely resembles the project of establishing a NATO-equivalent alliance in the South Atlantic, SATO (South Atlantic Treaty Organization). It was rejected by Brazil and Nigeria in the 1980s. 
Bruno Gomes Guimarães

\section{CONCLUSION}

Brazil has a clear maritime vocation. Geographically the country is inclined towards the ocean and, in the $21^{\text {st }}$ century, there has been political will to take advantage of this through many policies. Regional integration of South America fosters development, peace, and stability. Brazilian policies towards sub-Saharan African countries seem to have the same purpose.

This paper sought to explain the Brazilian geopolitical strategy towards the South Atlantic since 2000. The hypothesis was that Brazil has been seeking command over the ocean through the control of strategically important positions and through the curbing of extra-regional powers' influence in the region. It is only partially confirmed, because Brazil has not tried to establish military bases on geopolitically important locations nor challenged British possession over most of its South Atlantic islands. Brazilian initiatives point to a geopolitical strategy of ensuring sovereignty and independence rather than confrontation to established powers. Attempts to curb extra-regional powers' influence seek greater autonomy, not only for Brazil itself but also for all South Atlantic countries considered in the research.

As Corbett (1911) put it, the command of the sea, in times of peace, is a rhetorical expression that means a country has adequate naval positions and fleet to secure the actual command when war breaks out. Brazil has not tried to acquire naval positions outside its jurisdictional waters since 2000. On the other hand, Brazilian geopolitical strategy has aimed at securing a permanent local command of the Blue Amazon, i.e. protecting its sovereignty and territorial integrity (for instance, through SisGAAz and PROSUB). Historically, extra-regional powers have threatened and even waged war against Brazil in order to conquer territory or for purely commercial reasons. Therefore, Brazil's main goal is to have command of its own waters so that these scenarios do not come to happen again.

One can see from this geopolitical strategy that Brazil has had a defensive yet very firm posture in its international relations. Brazil has resolutely affirmed its sovereignty and strived towards greater independence vis-à-vis extra-regional powers present in the South Atlantic, with whom it has maintained friendly relations, even if sometimes marred by suspicions. Therefore, it has been a peaceful rise and, depending on Brazil, it will keep on going through the same path. 